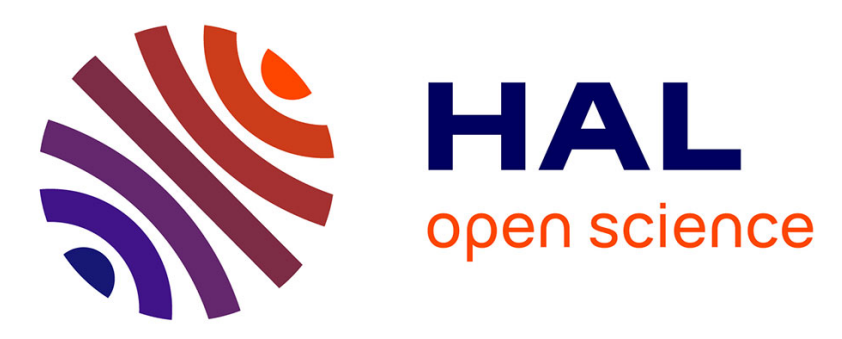

\title{
Limiting the pollutant content in the sewage sludge producer gas through staged gasification
}

\author{
Ana Belén Hernandez, Jean-Henry Ferrasse, Nicolas Roche
}

\section{To cite this version:}

Ana Belén Hernandez, Jean-Henry Ferrasse, Nicolas Roche. Limiting the pollutant content in the sewage sludge producer gas through staged gasification. Chemical Engineering and Technology, 2013, 36 (11), pp.1985-1996. 10.1002/ceat.201300103 . hal-00978823

\section{HAL Id: hal-00978823 \\ https://hal.science/hal-00978823}

Submitted on 26 Nov 2017

HAL is a multi-disciplinary open access archive for the deposit and dissemination of scientific research documents, whether they are published or not. The documents may come from teaching and research institutions in France or abroad, or from public or private research centers.
L'archive ouverte pluridisciplinaire HAL, est destinée au dépôt et à la diffusion de documents scientifiques de niveau recherche, publiés ou non, émanant des établissements d'enseignement et de recherche français ou étrangers, des laboratoires publics ou privés. 


\section{Limiting the Pollutant Content in the Sewage Sludge Producer Gas through Staged Gasification}

Ana Belén Hernández

Jean-Henry Ferrasse

Nicolas Roche

Sewage sludge gasification deals with the release of nitrogen and sulfur com-pounds, the main sources for pollutants during the final combustion. In order to handle these compounds, a staged gasification process is proposed. During the low-temperature thermal treatment of the first stage, nitrogen and sulfur com-pounds are removed from the solid fuel. The second stage converts the remaining solid into combustible compounds through gasification reactions. The producer gas obtained during this stage is compared to the producer gas of a simple gasifi-cation. The presence of pollutant precursors was considerably diminished during the staged experiments. A successful staged gasification may eliminate the need for downstream cleanup and thus limit the energy consumption. This work proves that staged gasification may be the key to obtain energy from waste fuel, limiting the concerns about pollutants.

Keywords: Biomass energy, Devolatilization, Kinetic model, Thermochemical conversion, Waste management

\section{Introduction}

Given the increasing production of sewage sludge (SS) $[1,2]$, which is a source of heavy metals, organic pollutants and pathogenic organisms, and the stringent norms concerning SS management [3-5], thermal conversion seems an attractive way of SS disposal. In fact, from the energetic point of view, SS is a heterogeneous biomass, as are other waste fuels, with a relatively high heating value close to that of brown coal [6]. The best established thermal technology is incineration [6], which can recover energy from hot exhaust gases. Nevertheless, incineration requires two major treatment operations: extensive gas cleaning, to match the emission limit values set for air pollutants according to directive 2000/76/EC [7], and safe disposal of the ashes, which contain considerable concentrations of potentially toxic metals [8-12].

Lately, several advanced thermal technologies have been introduced as a clear alternative to incineration $[2,13]$, such as pyrolysis or gasification. Thermal gasification consists in the conversion of biomass, typically between $700-900{ }^{\circ} \mathrm{C}$, into a

Correspondence: Dr. J.-H. Ferrasse (jean-henry.ferrasse@univ-amu.fr), M2P2, Laboratoire de Mécanique, Modélisation et Procédés Propres, Aix-Marseille University, CNRS, UMR 73401, Cedex 4, 13545 Aix-enProvence, France. producer gas rich in combustible compounds, such as $\mathrm{H}_{2}, \mathrm{CO}$, and $\mathrm{CH}_{4}$, and a solid residue [14]. Unlike pyrolysis, gasification is carried out with a gasifying agent, usually steam and/or air, the equivalence ratio is between $0.2-0.4$. As other thermal processes, SS gasification (SSG) enables the removal of organic pollutants and pathogenic organisms; it leads to a remarkable volume reduction of waste of approximately $70 \%$ of the solids' initial dry mass [2] and allows for the recovery of the sludge energy content [13]. Moreover, in view of the limited solubility of heavy metals retained in the gasified residues [14], SSG appears as an attractive alternative to landfilling as SS disposal route.

During gasification, two main mechanisms take place [15-18]: (i) devolatilization, i.e., fast pyrolysis in a reactive atmosphere, e.g., cracking, reforming, and oxidation, and (ii) char gasification. SS devolatilization starts at low temperature, from about $250^{\circ} \mathrm{C}$, and converts the fuel organic matter (OM) into volatiles and light gases [19-21]. It is a key conversion stage during gasification and combustion of biomass and waste fuels such as SS, given the high OM content in those fuels compared to fossil fuels $[17,22,23]$. Char gasification, with char including fixed carbon $(\mathrm{C})$ and mineral matter (MM), converts fixed carbon into light gases by heterogeneous and homogeneous reactions, commonly described between $700-900^{\circ} \mathrm{C}$.

Until now, research on SSG has mainly focused on the gas production yield and gas composition [24-30], as well as on heavy metal distribution [31-33] and tar formation [34-37]. 
Most of these key gasification aspects are, to some extent, common to other biomasses and waste fuels. For instance, tar formation, which takes place during devolatilization, reduces the efficiency of the conversion process, and limits the applications of the producer gas, may be considerably overcome with an accurate gasification technology, involving tar conversion to producer gas inside the gasifier [38,39]. The tar problem is common to coal, biomass, and waste fuels. However, a major drawback distinctive of SSG is the considerable amount of nitrogen present in SS (N-SS) as compared to other biomasses, which may be as high as $8 \%$ [6]. The presence of $\mathrm{N}$ compounds in the producer gas may lead to air pollutants such as $\mathrm{NO}_{\mathrm{x}}$ during the final combustion [40-44]. In addition, SS may also contain some sulfur (S-SS) giving rise to S pollutants; the $S$ contents in SS can be comparable to those of coals [6]. Although there is not much information on the $S$ behavior during SSG or SS pyrolysis, studies on coal pyrolysis and coal gasification have shown the production of $\mathrm{H}_{2} \mathrm{~S}, \mathrm{COS}, \mathrm{SO}_{2}$, and $\mathrm{CS}_{2}$ [45-49].

Recently, part of the research efforts have focused on the conversion of N-SS to $\mathrm{N}$ compounds during SSG [50,51], showing that $\mathrm{NH}_{3}, \mathrm{HCN}, \mathrm{N}$ volatiles, and molecular nitrogen are the main $\mathrm{N}$ compounds formed, while a smaller part of the $\mathrm{N}-\mathrm{SS}$ (about $5 \%$ of the initial N-SS) is retained in the solid residue. These studies, in comparison with SS pyrolysis studies [52-54], show the formation of similar N compounds; however, less than $20 \%$ of the initial $\mathrm{N}$ content is still present in the char obtained after pyrolysis at $700{ }^{\circ} \mathrm{C}$ [52]. In view of these facts, devolatilization during SSG seems to be responsible for most the N-SS conversion.

In this study, the behaviors of N-SS and S-SS during SSG were investigated considering two steps: a low-temperature SS devolatilization step followed by a char-SS gasification step. The aim was the thermal separation of pollutant precursors and combustible compounds by the staged process conceptualized in Fig. 1, operating at two different temperatures. The first stage, here called the cleanup stage, involves low-temperature devolatilization. This stage, in theory, produces $\mathrm{N}$ - and $\mathrm{S}$-rich gases as well as $\mathrm{N}$ - and S-poor char. This char would be gasified in the second stage, here called the gasification stage, to produce combustible compounds. Devolatilization gases may contain some permanent gases, mainly $\mathrm{CO}, \mathrm{CH}_{4}, \mathrm{H}_{2}$, and $\mathrm{CO}_{2}$. In order to take advantage of their combustible value, these gases, after removal of pollutant precursors by lowtemperature treatment, could be reintroduced into the gasification stage or directly burned. Then again, any pollutants obtained could be retreated by the wastewater treatment plant. The final producer gas of this staged gasification could be directly burned with limited concerns regarding pollutants. Therefore, this advanced process would be a clear alternative to incineration or simple gasification. The latter technologies produce high-temperature gases containing pollutants or pollutant precursors. These gases have to be treated for pollutant removal by expensive hot treatment gas or by cooling them down, with considerable loss in energetic value.

The feasibility of staged gasification systems has already been proven [55-58] and their potential to eliminate the tar content has been reported [39]: The tar content of the producer gas of staged gasification may be about 40 times lower than that obtained with a single-stage reactor under similar operating conditions [55]. This is due to the separation of the pyrolysis/devolatilization zone, usually at about $600^{\circ} \mathrm{C}$, from the gasification zone, where temperatures range from $800-1200^{\circ} \mathrm{C}$. Tars formed during the first stage, the pyrolysis/devolatilization step, are decomposed in the second stage, the gasification zone. In addition to the cleaner gas, staged gasification leads to higher char conversion, when compared to single-staged units of the simple gasification, leading to higher process efficiency [59].

In view of these facts, staged gasification seems to be the better technology to implement SSG; however, the behaviors of $\mathrm{N}$ and $S$ pollutant precursors in the different stages remain unknown. Experiments with wood board [60] have shown that a low-temperature pyrolysis stage, about $250^{\circ} \mathrm{C}$, before the pyrolysis/gasification step decreases the $\mathrm{NH}_{3}$ formation by a factor of 6-8 and prevents HCN production. However, the $\mathrm{N}$ functionalities in SS, derived from microbial organisms, ammonium salt, and $\mathrm{NH}_{3}$ adsorbed in the wastewater treatment plant $[54,61,62]$, differ considerably from those in other biomasses, and so the $\mathrm{N}$ compounds formed during SS gasification may behave differently. Hence, in order to deal with pollutant formation, a larger knowledge on the $\mathrm{N}$ and $\mathrm{S}$ behavior during SSG is needed.

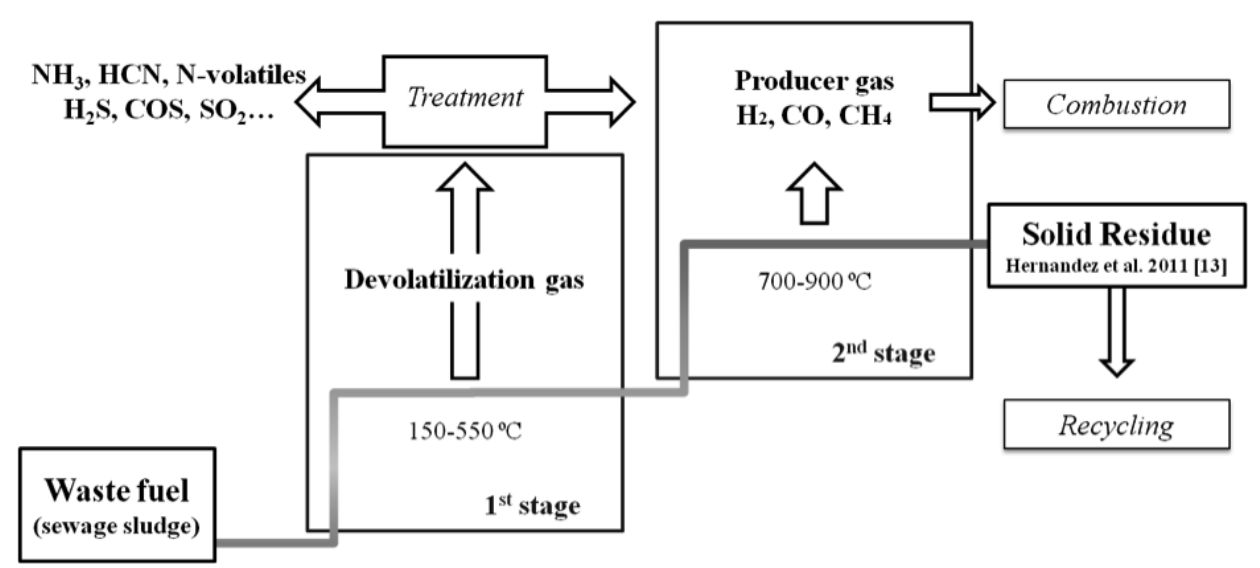

Figure 1. Schematic representation of the staged gasification process. 
This study aims to investigate the removal of $\mathrm{N}$ and $\mathrm{S}$ pollutant precursors during staged gasification (Fig. 1). Hence, lowtemperature experiments, reproducing the cleanup stage, and staged experiments, reproducing the cleanup and gasification stages, were performed considering different cleanup stage temperatures. These experiments allowed to (i) determine the main $\mathrm{N}$ and $\mathrm{S}$ compounds formed during SS devolatilization at different temperatures below $600^{\circ} \mathrm{C}$, (ii) study the lumped kinetic parameters of the cleanup stage, and (iii) analyze the influence of the cleanup stage on the overall process.

\section{Materials and Methods}

Dewatered SS was sampled from a municipal wastewater plant, servicing about 200000 population equivalents (p.e.). In order to avoid variations in SS composition, a large amount of well-mixed sludge was sampled at once and subsequently frozen in separate portions. Elementary and proximate analyses (Tab. 1) show that the SS sampled has a composition similar to that typically found in the literature [2]. Prior to the experiments, portions of the SS (about $30 \mathrm{~g}$ and $5 \mathrm{~mm}$ thick) were placed on a ceramic support and dried in a ventilated oven at $80^{\circ} \mathrm{C}$ for $24 \mathrm{~h}$ (leading to a moisture content of about $18 \mathrm{wt} \%$ ).

The ceramic support containing the dried SS (DSS) sample was introduced into an electrically heated $(2.34 \mathrm{~kW})$ vertical bench-scale tubular reactor (Fig. 2), in which only the central zone is heated $(300 \mathrm{~mm}$ of heated length and $114 \mathrm{~mm}$ in inner diameter).

The cleanup stage experiments were carried out with steam produced by a laboratory water heater and pushed by inert gas (about $45 \mathrm{~mL} \mathrm{~min}^{-1}$ argon, i.e., $0.4 \mathrm{~g}_{\mathrm{AR}} / \mathrm{g}_{\mathrm{H}_{2} \mathrm{O}}$ ), at low and fast heating rates. During the low heating rate experiment, the reactor, with the DSS sample placed in the central zone, was heated from 105 to $430{ }^{\circ} \mathrm{C}$, at $2^{\circ} \mathrm{C} \mathrm{min}^{-1}$. During the fast heating rate experiments, the sample was hung at the top part of the reactor (the nonheated zone) until the target temperature $\left(230-530^{\circ} \mathrm{C}\right)$ was reached in the central zone (the heated zone). Then, the sample was slipped down to the central zone. The variation in the ambient temperature surrounding the sample was above $100^{\circ} \mathrm{C} \mathrm{s}^{-1}$. Gas production was continuously monitored so that the experiments were finished at the end of this gas production. These isothermal experiments revealed the suitable temperatures to carry out the cleanup stage and allowed studying the lumped kinetic parameters of this stage.

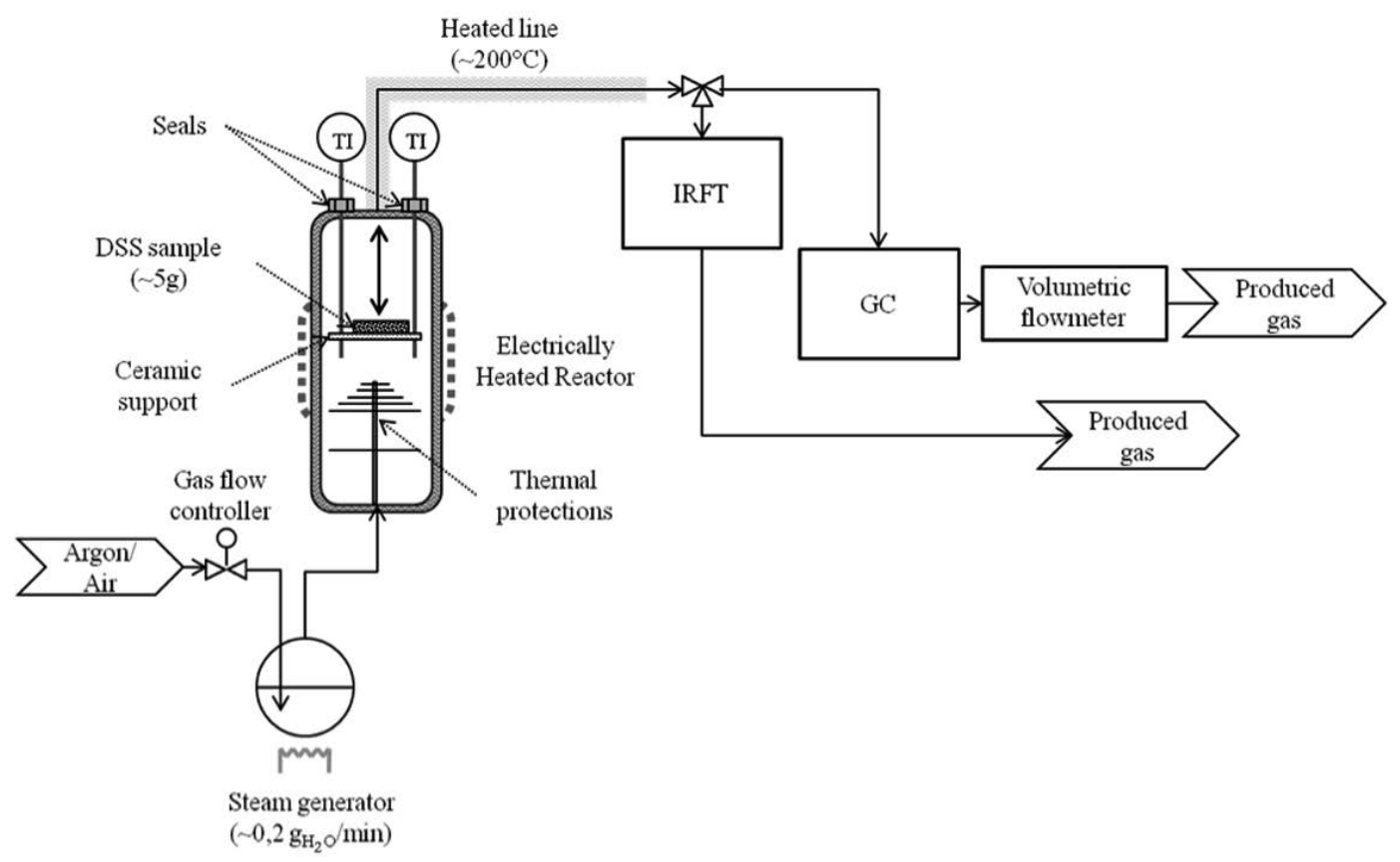

Figure 2. Experimental setup. 
Finally, the influence of the cleanup stage on the global process, i.e., the combustible compounds and pollutant precursors in the producer gas, was investigated. These experimental series started by fast heating rate cleanup experiments, followed by heating up of the reactor to $900{ }^{\circ} \mathrm{C}$ at about $15^{\circ} \mathrm{C} \mathrm{min}{ }^{-1}$. The reactor was purged with argon at the end of the first stage. During the second stage, the char sample remained in the central zone and steam (pushed by argon) was supplied. It should be highlighted that the staged experiments were performed in situ, i.e., the solid was not cooled between the two stages, which is more representative of staged gasification conditions. The thermal history of the char influences its reactivity [15]. A single-stage SSG experiment was also performed to compare the producer gas with and without cleanup stage. During this single-stage SSG experiment, the reactor was heated up from 105 to $900{ }^{\circ} \mathrm{C}$ with steam (argon pushed), and so only the gasification stage was performed, without being preceded by a first cleanup stage.

The gas produced in each experiment passed through a heated line, thus avoiding condensation, before being analyzed online by gas chromatography (GC; Varian 3800) and Fourier transform infrared spectroscopy (FTIR; Spectrum 600, Perkin Elmer). The gas chromatograph was calibrated to measure the $\mathrm{H}_{2}$ and $\mathrm{CO}_{2}$ contents in gas (volumetric concentration, vol \%), and the analyses were performed at $80^{\circ} \mathrm{C}$, every $12-15 \mathrm{~min}$. The FTIR cell (pathway $1.2 \mathrm{~m}$ ) was heated at $155^{\circ} \mathrm{C}$ to avoid condensation inside. In the FTIR analyses, the volumetric concentrations of $\mathrm{CO}, \mathrm{CH}_{4}$, and $\mathrm{NH}_{3}$ in the produced gas were measured every $2 \mathrm{~min}$ (4 counts per measurement). Other compounds, such as $\mathrm{COS}, \mathrm{CH}_{3}-\mathrm{OH}, \mathrm{CH}_{3}-\mathrm{COOH}, \mathrm{C}_{2} \mathrm{H}_{6}$, and $\mathrm{H}_{2} \mathrm{O}$, were detected by FTIR, and their evolution was followed during the experiments.

Given the complexity of spectral data, due to several compounds present with different behavior, the mixture spectra matrix was treated with the SIMPLISMA algorithm (SIMPLeto-use Interactive Self-modeling Mixture Analysis [63]). This specific approach was previously used to follow the gas evolution during the thermal treatment of SS by FTIR coupled with thermogravimetry [64].

The yields of the gases passing through the GC and FTIR systems were measured by a volumetric flow meter. This allowed the determination of the instantaneous production (in $\mathrm{mL} \mathrm{min}^{-1}$ ) and the total production (in $\mathrm{mL}$ ) of each quantified compound. Finally, given the considerable volume of the FTIR cell $(760 \mathrm{~mL}$; the gas flow observed was commonly below $100 \mathrm{~mL} \mathrm{~min}^{-1}$ ) the residence time distribution (RTD) was used to calculate the real production signal at the cell inlet, considered similar to the reactor outlet signal. This allowed for correct determination of the kinetic parameters. More practical details on the protocol used can be found in [65].

At the end of each experiment, the solid residues obtained were weighed and analyzed by elemental analyses (CHNS). Element losses were calculated as follows:

$\Delta E(\%$ d.m. $)=100-\frac{E_{\text {residue }}(\% \text { d.m. })}{E_{\mathrm{SS}}(\% \text { d.m. })} \times\left(100-\Delta m^{\text {sample }}\right)$

where $E$ is the content of the considered element $(E=\mathrm{C}, \mathrm{H}, \mathrm{N}$, or S) on a dry basis (d.m.) and $\Delta m$ refers to the sample weight loss.

\section{Results and Discussion}

\subsection{Gas Evolution during the Devolatilization Experiment at Low Heating Rate}

Carbon dioxide $\left(\mathrm{CO}_{2}\right)$, carbon monoxide $(\mathrm{CO})$, and ammonia $\left(\mathrm{NH}_{3}\right)$ (Fig. $\left.3 \mathrm{a}\right)$, together with steam $\left(\mathrm{H}_{2} \mathrm{O}\right)$, were the main compounds detected in the gas analyzed during the experiment performed at low heating rate $\left(2^{\circ} \mathrm{C} \mathrm{min}{ }^{-1}\right)$. Other compounds such as acetic acid $\left(\mathrm{CH}_{3}-\mathrm{COOH}\right)$, methanol $\left(\mathrm{CH}_{3}-\mathrm{OH}\right)$, ethane $\left(\mathrm{C}_{2} \mathrm{H}_{6}\right)$, and carbonyl sulfide (COS) (Fig. 3 b) were also detected, but not quantified. Finally, methane $\left(\mathrm{CH}_{4}\right)$ was detected, but the intensity of the corresponding peaks was too weak compared to the baseline. It can be observed (Fig. 3) that the production of most of the compounds increased with temperature until a maximum value was reached, and then decreased. These maximum values correspond to temperatures below $430^{\circ} \mathrm{C}$ (target temperature of this experiment), meaning that the devolatilization mechanism was already complete before this temperature was achieved.

$\mathrm{CO}_{2}$ production (Fig. 3 a) started at low temperature (150$200^{\circ} \mathrm{C}$ ), and it increased sharply when the reactor temperature reached $250^{\circ} \mathrm{C} . \mathrm{CO}_{2}$ production at low temperature was also observed in the literature $[61,66,67]$, and it was supposed to originate from the hydrolysis of amino acids or the decomposition of bicarbonate present in the SS [61]. CO production started at $315^{\circ} \mathrm{C}$ and reached the highest values at about $340^{\circ} \mathrm{C}$. The total production of $\mathrm{CO}$ and $\mathrm{CO}_{2}$ at the end of this experiment represented about $21 \%$ of the initial carbon content $\left(18.4 \% \mathrm{CO}_{2}\right.$ and $\left.2.8 \% \mathrm{CO}\right)$.

$\mathrm{NH}_{3}$ production started at $100^{\circ} \mathrm{C}$, increasing slowly until $350{ }^{\circ} \mathrm{C}$ (Fig. $3 \mathrm{a}$ ), when the total $\mathrm{NH}_{3}$ produced represented about $8.6 \%$ of the $\mathrm{N}-\mathrm{SS} . \mathrm{NH}_{3}$ measured in the initial SS, as a consequence of the wastewater treatment $[53,54,61,62]$, was at about $0.56 \mathrm{wt} \%$ d.m., representing $8.54 \%$ of the total N-SS. Therefore, it is believed that the observed $\mathrm{NH}_{3}$ at temperatures below $350^{\circ} \mathrm{C}$ resulted from the $\mathrm{NH}_{3}-\mathrm{SS}$ evaporation. Between 350 and $380^{\circ} \mathrm{C}, \mathrm{NH}_{3}$ production increased sharply, which is related to the thermal decomposition of proteins [51-54]. This thermal phenomenon may also produce $\mathrm{N}$ volatiles [53]. The total $\mathrm{NH}_{3}$ production at the end of the experiment represents $33.6 \%$ of the initial N-SS. Peaks of hydrogen cyanide (HCN) and fulminic acid (HCNO) were also sometimes present among the spectral data, but the peak intensities compared to the baseline were too weak to correctly follow their evolution. $\mathrm{NH}_{3}$ was therefore the most important $\mathrm{NO}_{\mathrm{x}}$ precursor detected. This has also been reported in the literature [43]. Hence, for this study, $\mathrm{NH}_{3}$ was considered as a model $\mathrm{N}$ compound and used to survey the $\mathrm{N}$ removal during the cleanup stage.

COS production started at about $250^{\circ} \mathrm{C}$ and reached its maximum values at about $340^{\circ} \mathrm{C}$. COS production during SSG is not usually mentioned in the literature; however, this compound is known to be formed during coal gasification [45-49]. It is known to decompose $[68,69]$ at temperatures below $635^{\circ} \mathrm{C}$ to give $\mathrm{CO}_{2}$ and $\mathrm{CS}_{2}$ or, at higher temperatures, to give $\mathrm{CO}$ and $\mathrm{S}$. Also, $\mathrm{COS}$ hydrolysis, according to $\mathrm{COS}+\mathrm{H}_{2} \mathrm{O} \rightleftarrows \mathrm{H}_{2} \mathrm{~S}+\mathrm{CO}_{2}$ [70], is known to start at about 

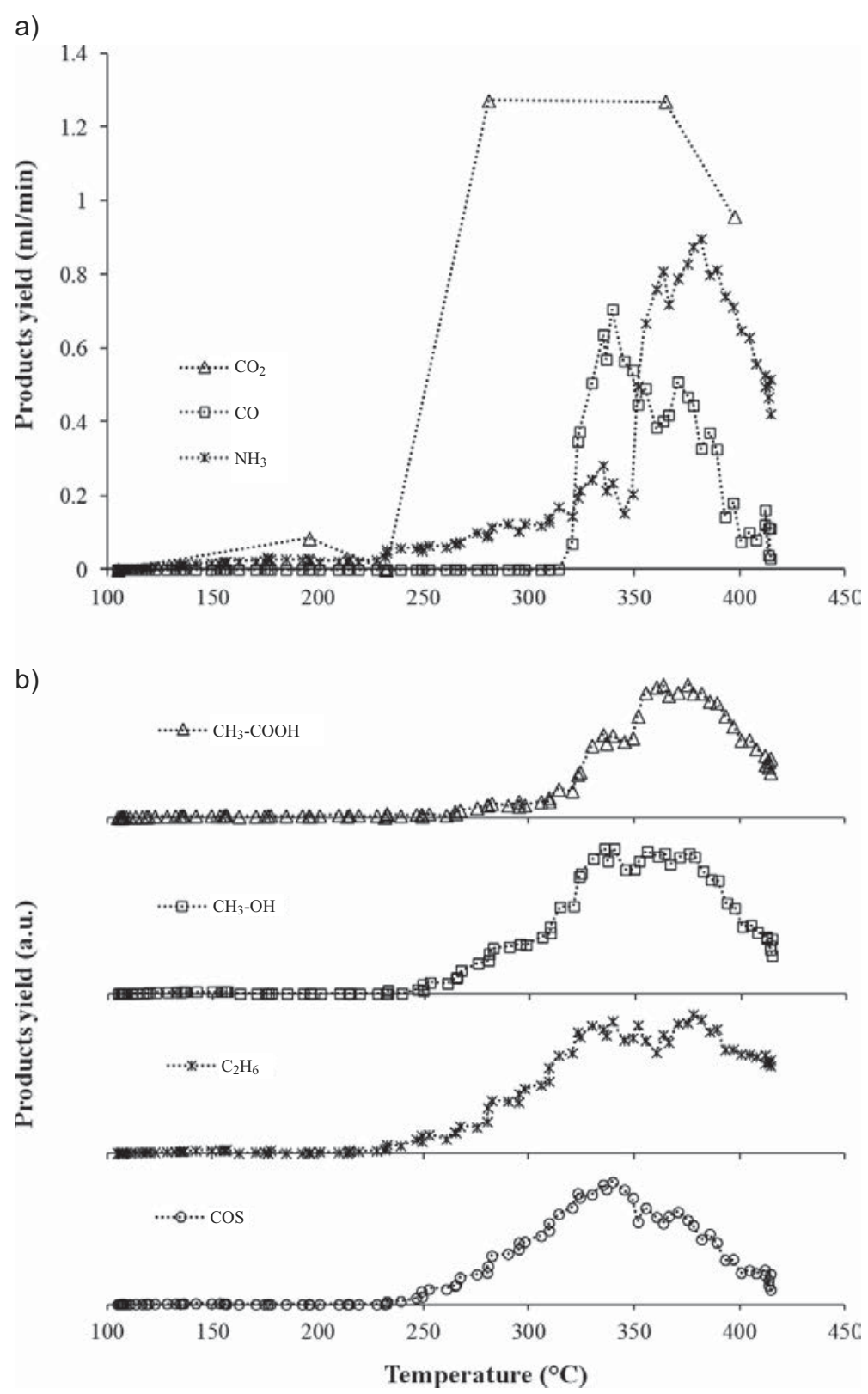

Figure 3. Product yields, in $\mathrm{mL} \mathrm{min}^{-1}$ under standard conditions, during the lowheating rate experiment $\left(2^{\circ} \mathrm{Cmin}^{-1}\right)$ to $430^{\circ} \mathrm{C}$. (a) $\mathrm{CO}_{2}, \mathrm{CO}$, and $\mathrm{NH}_{3}$ in $\mathrm{mL} \mathrm{min}^{-1}$, (b) $\mathrm{CH}_{3}-\mathrm{COOH}, \mathrm{CH}_{3}-\mathrm{OH}, \mathrm{C}_{2} \mathrm{H}_{6}$, and $\mathrm{COS}$ (in a.u.).

$400{ }^{\circ} \mathrm{C}$ and to be favored by iron-based catalysts. The iron contents of the DSS samples are at about $3.8 \mathrm{wt} \%$ d.m. However, during these experiments, neither $\mathrm{H}_{2} \mathrm{~S}$ nor $\mathrm{CS}_{2}$ was detected by FTIR, probably due to the detection limits, since the $\mathrm{S}$ content in the DSS samples is lower than $0.1 \mathrm{wt} \% \mathrm{~d} . \mathrm{m}$. (Tab. 1). Therefore, COS production, as the only $\mathrm{S}$ compound detected, was used during the study of the cleanup stage to follow the removal of S.

\subsection{Devolatilization Experiments at Fast Heating Rate}

\subsubsection{Weight and Element Losses}

Fig. 4 shows the weight losses of samples and the element (CHNS) losses during the experiments as a function of the target temperature, as well as the nitrogen and sulfur loss as a function of the fixed carbon loss. As can be observed, the weight losses of the samples (Fig. 4 a) treated at around $530{ }^{\circ} \mathrm{C}$ and lower temperatures correspond to the organic matter $(\mathrm{OM})$ devolatilization. However, the low heating rate experiment (Fig. 3) with the target temperature of $430^{\circ} \mathrm{C}$ showed that devolatilization was completely achieved when the reactor reached about $380^{\circ} \mathrm{C}$. Moreover, the weight loss plot (Fig. 4 a) shows a stabilization between 330 and $480^{\circ} \mathrm{C}$. These observations can be explained by the different OM fractions contained in SS volatilizing at different temperatures: biodegradable materials, organic polymers, and non-degradable materials such as cellulosic compounds [19-21]. Finally, the simple gasification experiment at $900{ }^{\circ} \mathrm{C}$ was also included in this plot, showing an increase in weight loss, mainly due to char gasification reactions.

Substantial differences may be detected in the behavior of different elements with changing temperature (Fig. 4 b), meaning a different composition of devolatilization gases at each temperature. Tab. 2 summarizes the empirical formulas of molecules representing the global composition of volatiles for each temperature range, as well as the corresponding weight losses, i.e., the mass fraction assigned to each molecular formula.

As can be observed in Fig. $4 \mathrm{c}$, the nitrogen loss evolved similarly to the fixed carbon loss, whereas the hydrogen loss increased faster and the sulfur loss took place mainly between 330 and $530{ }^{\circ} \mathrm{C}$, i.e., 30 and $60 \%$ of $\mathrm{C}$ conversion; Fig. 4 d. The solid obtained at $530{ }^{\circ} \mathrm{C}$ contains about 26 wt $\%$ d.m. of $\mathrm{C}, 3 \mathrm{wt} \% \mathrm{~d} . \mathrm{m}$. of $\mathrm{N}$, and $0.2 \mathrm{wt} \%$ d.m. of S. This means that $39 \%$ of the initial C remained in the char, available to produce combustible gases at higher temperatures during the gasification stage, while 70 and $86 \%$ of the initial $\mathrm{N}$ and S, respectively, were removed. Hence, a cleanup stage at about $530^{\circ} \mathrm{C}$ produces a char relatively poor in $\mathrm{N}$ and $\mathrm{S}$, limiting the final pollutant formation.

\subsubsection{Influence of the Temperature on the Gas Produced During the Cleanup Stage}

The carbon loss in the samples can be mainly explained by gas and tar formation during the experiments. Among the gas compounds, $\mathrm{CO}_{2}$ and $\mathrm{CO}$ were the main $\mathrm{C}$ compounds. In 

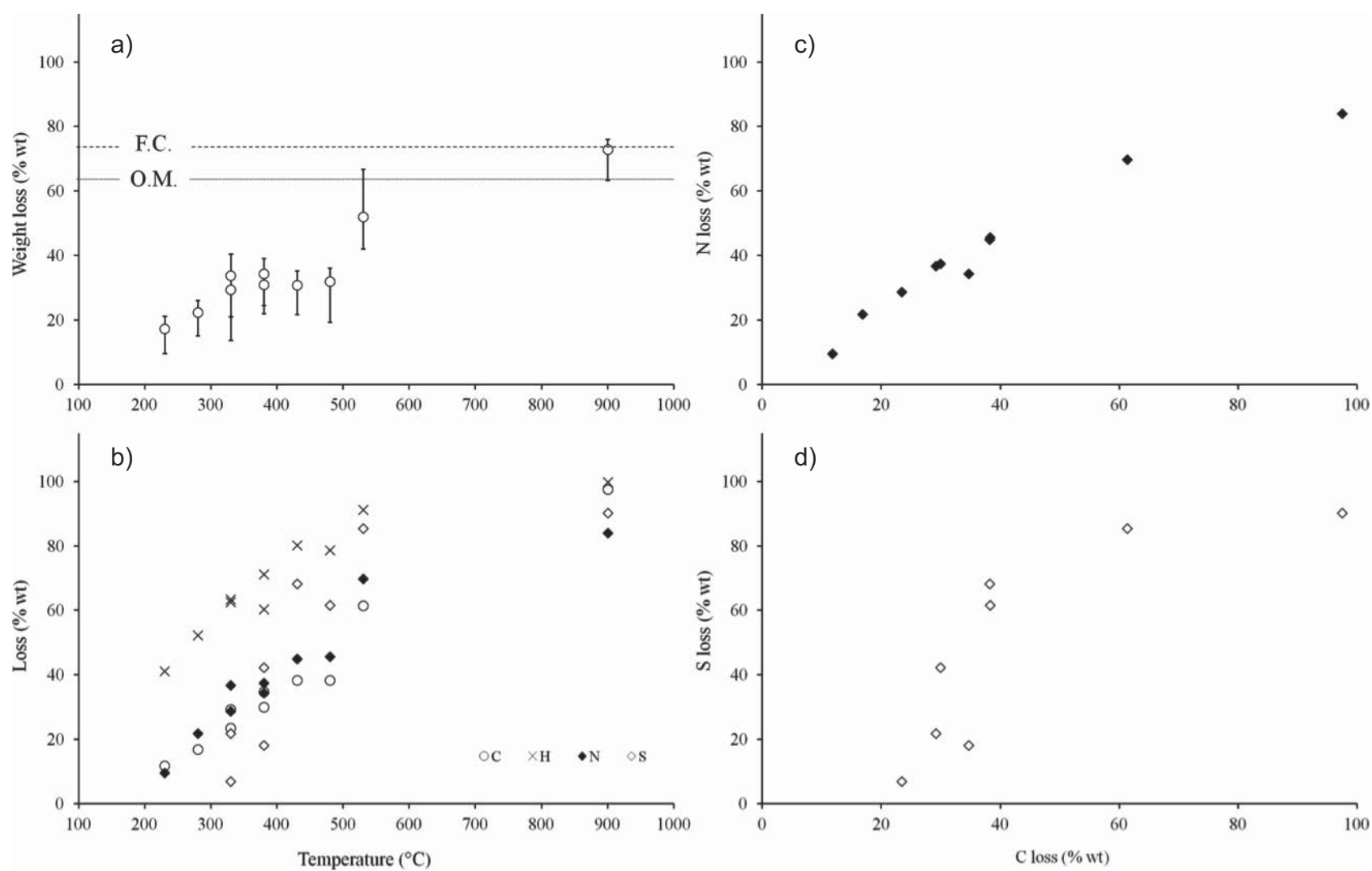

Figure 4. Influence of temperature (a) on sample weight loss and (b) on fixed carbon, hydrogen, nitrogen, and sulfur loss during the experiments. OM and FC weights corresponding to the organic matter and the fixed carbon contained in DSS, respectively. (c) nitrogen and (d) sulfur loss as a function of fixed carbon loss.

Table 2. Empirical formulas representing the composition of the devolatilization gases for each temperature range.

\begin{tabular}{llc}
\hline $\begin{array}{l}\text { Temperature range } \\
{\left[{ }^{\circ} \mathrm{C}\right]}\end{array}$ & Empirical formula & $\begin{array}{l}\text { Mass fraction } \\
{[\mathrm{wt} \% \text { d.m. }]}\end{array}$ \\
\hline $150-180$ & $\mathrm{CH}_{10} \mathrm{~N}_{0.1} \mathrm{O}$ & 8.25 \\
$180-230$ & $\mathrm{CH}_{5} \mathrm{~N}_{0.1} \mathrm{O}$ & 18.1 \\
$230-280$ & $\mathrm{CH}_{4} \mathrm{~N}_{0.3} \mathrm{O}_{0.5}$ & 7.9 \\
$280-330$ & $\mathrm{CH}_{3} \mathrm{~N}_{0.1} \mathrm{~S}_{0.01} \mathrm{O}_{0.6}$ & 10.8 \\
$330-380$ & $\mathrm{CH}_{2} \mathrm{~N}_{0.2} \mathrm{~S}_{0.06} \mathrm{O}_{0.3}$ & 2.3 \\
$380-430$ & $\mathrm{CH}_{2} \mathrm{~N}_{0.1} \mathrm{~S}_{0.03}$ & $\sim 0$ \\
$430-530$ & $\mathrm{CH}_{1.5} \mathrm{~N}_{0.1} \mathrm{~S}_{0.02}$ & 1.8 \\
\hline
\end{tabular}

Only organic oxygen is considered in these formulas. As a reference, the empirical formula representing the SS samples is $\mathrm{CH}_{1.9} \mathrm{~N}_{0.7} \mathrm{~S}_{0.01} \mathrm{O}_{0.7}$ (Tab. 1). d.m.: Dry matter

order to optimize the staged process, combustible compounds produced during the low-temperature stage, such as CO, should be recovered and introduced in the second stage. Therefore, this compound was followed during the low temperature experiments. The production of $\mathrm{NH}_{3}$ and $\mathrm{COS}$ was followed to study the $\mathrm{N}$ and $\mathrm{S}$ removal during the cleanup stage. Fig. 5 shows the cumulated amounts of $\mathrm{CO}, \mathrm{NH}_{3}$ (in $\mathrm{mg} \mathrm{g}_{\mathrm{DSS}}^{-1}$ ) and COS (in arbitrary units, a.u.) produced during these experiments. Repetitions at 230,430 and $530{ }^{\circ} \mathrm{C}$ proved the reproducibility of the experiments. As illustration, Fig. 6 shows the close reproducibility of the $\mathrm{NH}_{3}$ release for these repetitions, especially at the initial moment.

In agreement with the low heating rate experiment (Fig. $3 \mathrm{a}$ ), $\mathrm{CO}$ production during the fast heating rate experiments (Fig. 5 a) was not detected at temperatures below $330^{\circ} \mathrm{C}$. CO production increased with increasing temperature, especially between 480 and $530^{\circ} \mathrm{C}$. The total $\mathrm{CO}$ produced at these temperatures represented about $34 \mathrm{mgg}_{\mathrm{DSS}}^{-1}\left(430^{\circ} \mathrm{C}\right)$ and $50 \mathrm{mg} \mathrm{g}$ DSS $\left(530^{\circ} \mathrm{C}\right)$.

$\mathrm{NH}_{3}$ was detected from experiments at the lowest temperature. In fact, it was detected during prior experiments [64], performed at $120^{\circ} \mathrm{C}$ with air, reproducing the thermal conditions during $\mathrm{SS}$ sample drying. $\mathrm{NH}_{3}$ production during SS drying has also been reported in [61]. This production was poor compared to the production detected during the devolatilization experiments at $230^{\circ} \mathrm{C}$. Fig. $5 \mathrm{~b}$ shows that the temperature enhances $\mathrm{NH}_{3}$ production during devolatilization. The total $\mathrm{NH}_{3}$ produced at $230{ }^{\circ} \mathrm{C}$ was amounted to about $2.5 \mathrm{mg}_{\mathrm{NH}_{3}} \mathrm{~g}_{\mathrm{DSS}}^{-1}$, and it increased to almost $9 \mathrm{mg}_{\mathrm{NH}_{3}} \mathrm{~g}_{\mathrm{DSS}}^{-1}$ at $430{ }^{\circ} \mathrm{C}$ and more than $11 \mathrm{mg}_{\mathrm{NH}_{3}} \mathrm{~g}_{\mathrm{DSS}}^{-1}$ at $530^{\circ} \mathrm{C}$. These first results concerning $\mathrm{NH}_{3}$ production during $\mathrm{SS}$ devolatilization with steam atmosphere (Fig. $5 \mathrm{~b}$ ) are in agreement with those 

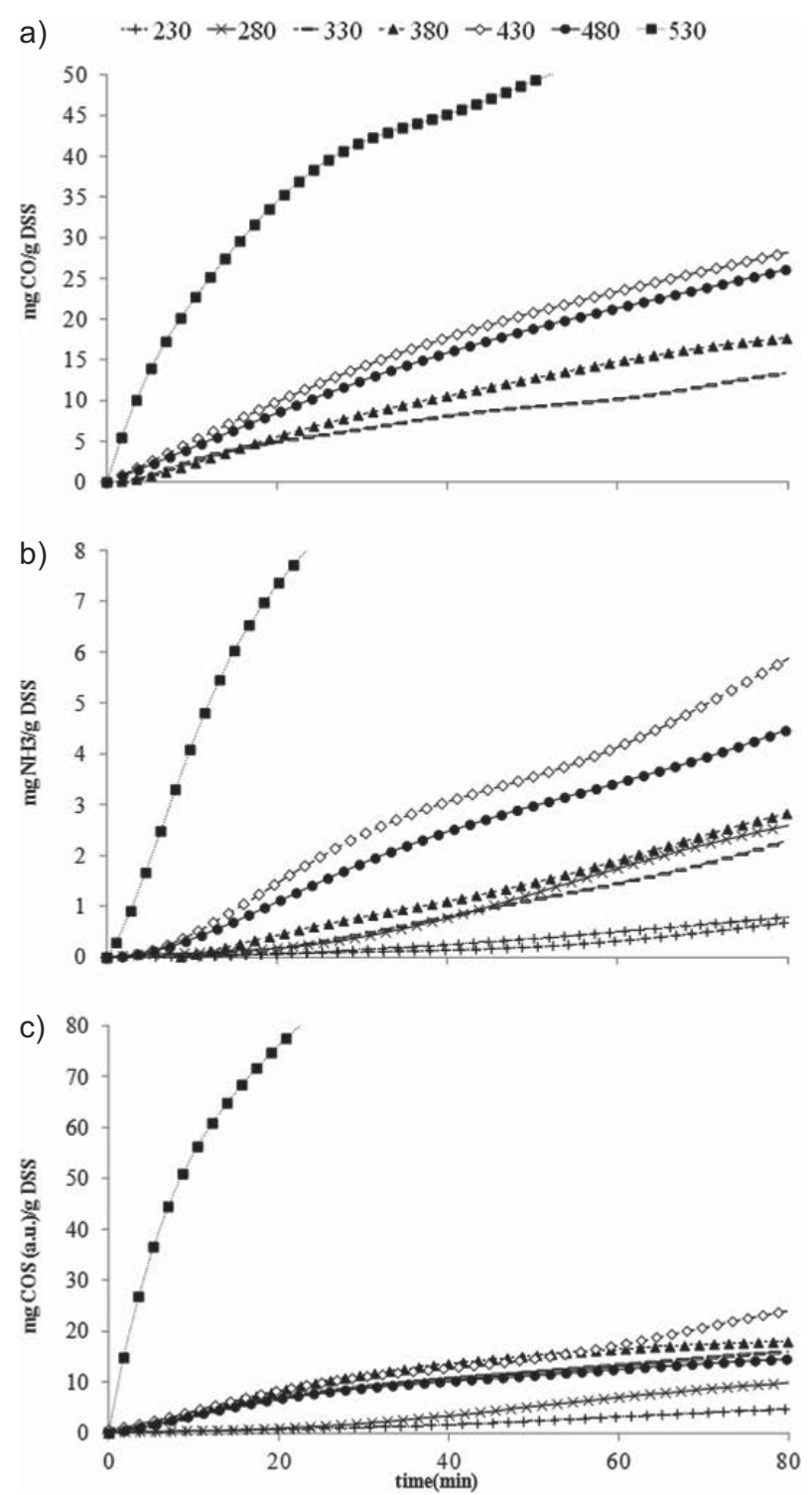

Figure 5. Cumulative yield of (a) $\mathrm{CO}$, (b) $\mathrm{NH}_{3}$, and (c) COS production during the cleanup experiments as a function of temperature $\left(230-530^{\circ} \mathrm{C}\right)$, in $\mathrm{mg} \mathrm{g}_{\text {DSS }}^{-1}$ (DSS: dried SS introduced into the reactor; a.u.: arbitrary units).

obtained during fast-pyrolysis experiments [54] (Fig. 7). This suggests that steam does not play a significant role in the $\mathrm{NH}_{3}$ release at temperatures below $530^{\circ} \mathrm{C}$. However, more experiments would be needed in order to determine how the steam supplied to the solid during its devolatilization influences the char reactivity during high-temperature reactions.

COS was not detected at temperatures below $230^{\circ} \mathrm{C}$, which agrees with the low-heating rate experiment. The sulfur contents in the SS samples are relatively low (Tab. 1) and so detection of $\mathrm{S}$ compounds implies a considerable $\mathrm{S}$ conversion. COS production increased with temperature (Fig $5 \mathrm{c}$ ), especially between 430 and $530^{\circ} \mathrm{C}$; it was tripled between these experiments.

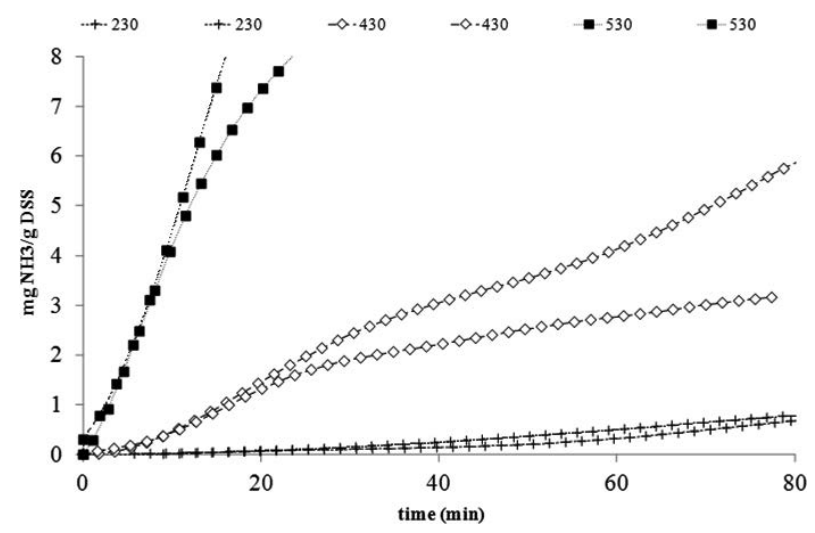

Figure 6. Reproducibility of the $\mathrm{NH}_{3}$ production cumulative yield during the cleanup experiments at 230,430 , and $530^{\circ} \mathrm{C}$, in $\mathrm{mg} \mathrm{g}_{\mathrm{DSS}}^{-1}$ (DSS: dried SS introduced into the reactor).

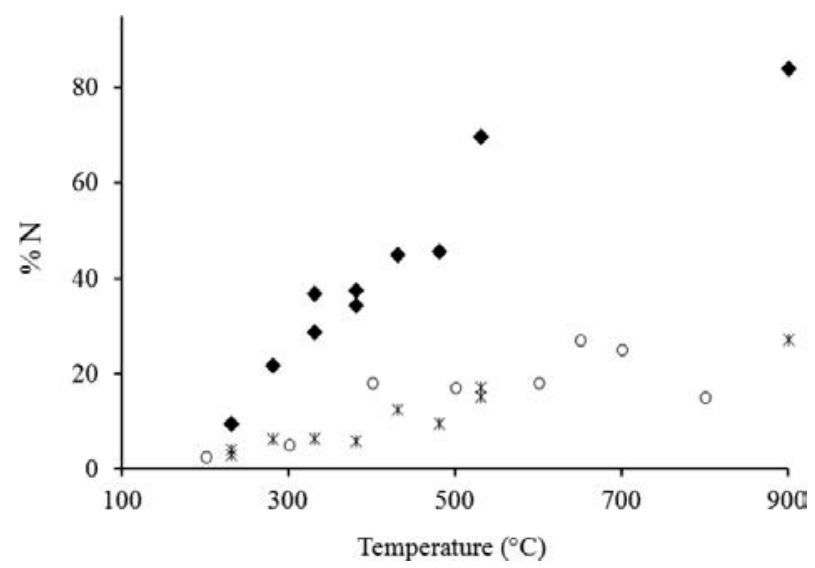

Figure 7. Total nitrogen loss in the samples $(\bullet)$ and nitrogen converted to $\mathrm{NH}_{3}(\% \mathrm{~N}-\mathrm{SS})$ (*) during the SSG experiments. Nitrogen conversion into $\mathrm{NH}_{3}$ during fast SS pyrolysis (O), as reported by Tian et al. 2002 [54].

Based on these results, temperatures between 430 and $530^{\circ} \mathrm{C}$ seem appropriate to separate most of the $\mathrm{N}$ and $\mathrm{S}$ compounds from the combustible compounds. The experiments at $480^{\circ} \mathrm{C}$, compared to the experiments at $430^{\circ} \mathrm{C}$, showed a similar performance regarding the weight and element losses (Figs. 4 and 5, Tab.2). This is explained by the presence, in SS, of different OM fractions with different behavior and devolatilization temperatures [19-21].

\subsubsection{Kinetics of the Cleanup Stage}

Since data on $\mathrm{NH}_{3}$ production from SS is scarce, it is difficult to complete a theoretical study explaining its production in the cleanup reactor. The isothermal experiments presented here allowed for the calculation of lumped kinetic parameters in the studied temperature range, representing the production of the compounds quantified. These kinetic expressions introduced into a gasification reaction model will allow an understanding of the pollutants formed during SSG and prevention of their presence in the producer gas. The CO kinetic para- 
meters were also determined in order to compare them with literature data and to validate the executed calculations.

Therefore, for each temperature, the initial slope of the $\mathrm{cu}$ mulative production of $\mathrm{CO}$ and $\mathrm{NH}_{3}$ (Fig. $5 \mathrm{a}$ and $\mathrm{b}$ ) was determined ( $r$, rate of production). The chemical regime is ensured by limiting the data to the initial moment, thus avoiding mass transfer effects. First-order reactions were considered for both compounds. The Arrhenius plot (Fig. 8), i.e., least squares fitting between the logarithm of the rate $r$ and the inverse of temperature, for $\mathrm{CO}$ and $\mathrm{NH}_{3}$ gives the respective pre-exponential factors and the activation energies (Tab. 3). The activation energies were around 49 and $44 \mathrm{~kJ} \mathrm{~mol}^{-1}$, respectively. Data concerning the kinetics of CO production during SS devolatilization were not found in the available literature. However, the SS devo-

Table 3. Kinetic parameters corresponding to $\mathrm{CO}$ and $\mathrm{NH}_{3}$ production during the experiments.

\begin{tabular}{lcc}
\hline Compound & $E_{\mathrm{a}}\left[\mathrm{kJ} \mathrm{mol}^{-1}\right]$ & $A_{0}\left[\mathrm{~min}^{-1}\right]$ \\
\hline $\mathrm{CO}$ & 49.05 & 93.16 \\
$\mathrm{NH}_{3}$ & 43.76 & 9.40 \\
\hline
\end{tabular}

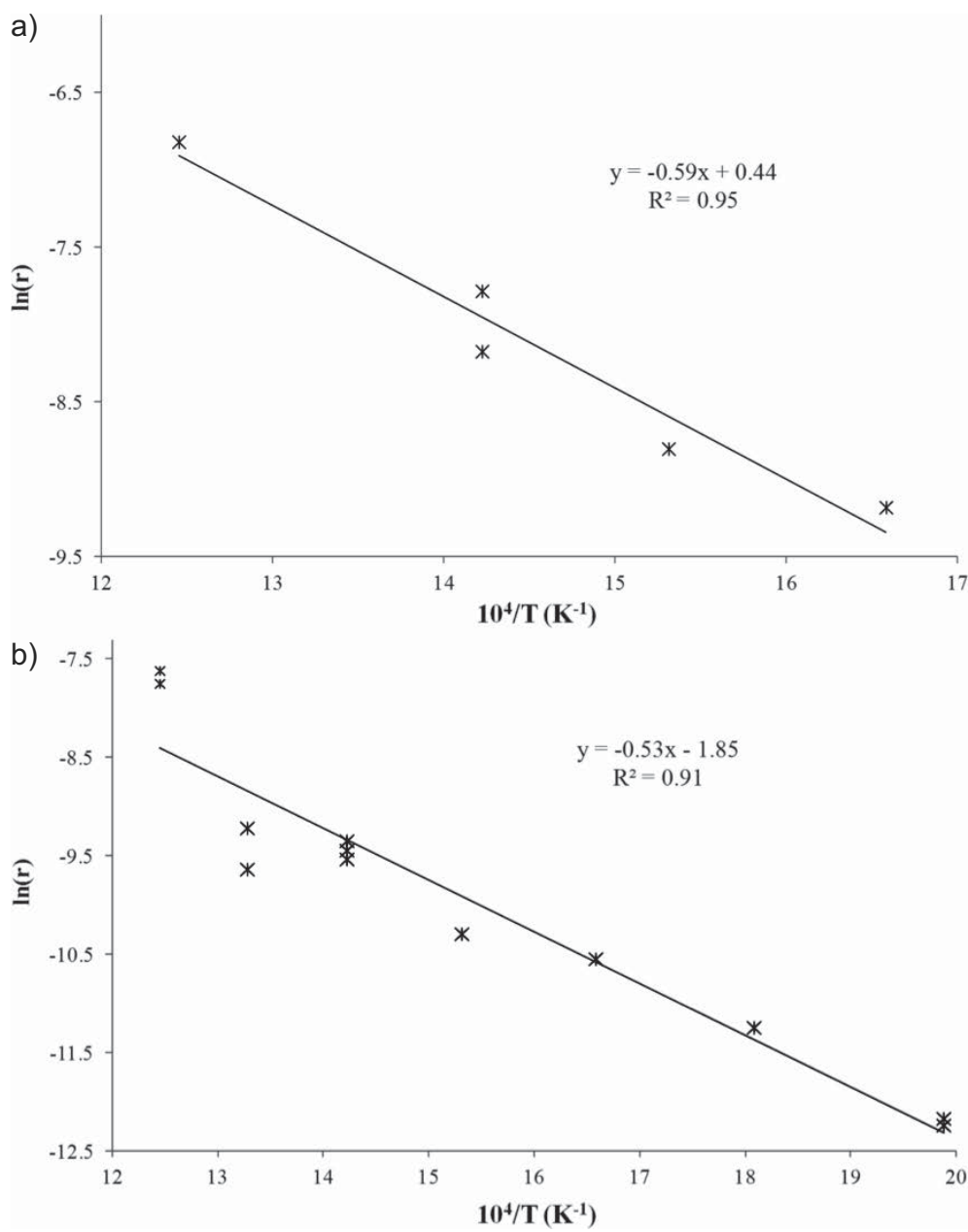

Figure 8. Determination of the (a) $\mathrm{CO}$ and (b) $\mathrm{NH}_{3}$ kinetic parameters with regard to the Arrhenius law. latilization and pyrolysis kinetic data, determined by thermogravimetric methods at a fast heating rate $[71,72]$, are in good agreement with the results obtained here.

\subsection{Influence of the Cleanup Stage on Pollutant Removal and Combustible Compound Production}

As it was previously discussed, the removal of pollutants increased considerably between 430 and $530^{\circ} \mathrm{C}$. However, the high $\mathrm{CO}$ production at $530^{\circ} \mathrm{C}$ may not be interesting for the global process, as carbon conversion should be maximized in the second stage. In order to investigate the influence of the cleanup stage on the global process, the producer gases evolved from the simple and staged experiments were compared. During these experiments, samples of DSS (single-stage experiments) and char obtained after the cleanup stages at 430,480 and $530^{\circ} \mathrm{C}$ (staged experiments) were gasified at $900{ }^{\circ} \mathrm{C}$ with steam (pushed by argon). Fig. 9 shows the evolution of producer gas during staged gasification at $430{ }^{\circ} \mathrm{C}$ (right side) and $530^{\circ} \mathrm{C}$ (left side). It can be observed that $\mathrm{H}_{2}$ and $\mathrm{CO}$, the combustible compounds, were mainly produced in the second stage while $\mathrm{NH}_{3}$ and COS, the pollutant precursors, were produced in both stages, but mainly in the first one. This means that thermal separation of the pollutant precursors and the combustible compounds was, to some extent, well achieved during the staged experiments.

Fig. 10 shows the evolution of producer gas during a simple gasification experiment. The total values of production of $\mathrm{H}_{2}, \mathrm{CO}, \mathrm{NH}_{3}$, and $\mathrm{COS}$ during the cleanup experiments, staged experiments, and simple gasification experiment are reported in Tab. 4. As can be observed, the production in staged gasification (cleanup plus gasification stage) is lower than the production in simple gasification. This should be partially due to the cleanup stage, which may influence the product distribution, reducing the total gas production and favoring the solid product.

Simple gasification at $900{ }^{\circ} \mathrm{C}$ produced about $25 \mathrm{~mL}_{\mathrm{NH}_{3}} \mathrm{~g}_{\mathrm{DSS}}^{-1}$, while the second stage of the staged gasification at $430{ }^{\circ} \mathrm{C}$ produced only $3.3 \mathrm{~mL}_{\mathrm{NH}_{3}} \mathrm{~g}_{\mathrm{DSS}}^{-1}$, which is a reduction of about $87 \%$. Staged gasification at $530^{\circ} \mathrm{C}$ reduced the $\mathrm{NH}_{3}$ production during the second stage to $0.45 \mathrm{~mL}_{\mathrm{NH}_{3}} \mathrm{~g}_{\mathrm{DSS}}^{-1}$, an $\mathrm{NH}_{3}$ reduction of about $98 \%$. Besides, it should be remarked that $\mathrm{HCN}$ and HCNO peaks were detected during the simple gasification experiment, but not during the second stage of staged gasification.

The interesting effect of staged SSG was also proved by the COS reduction during the second stage of the staged experiments. It was not possible to follow the COS production during the simple gasification experiment, due to the high amount of compounds formed in a short period of time. However, during the first stage COS production 


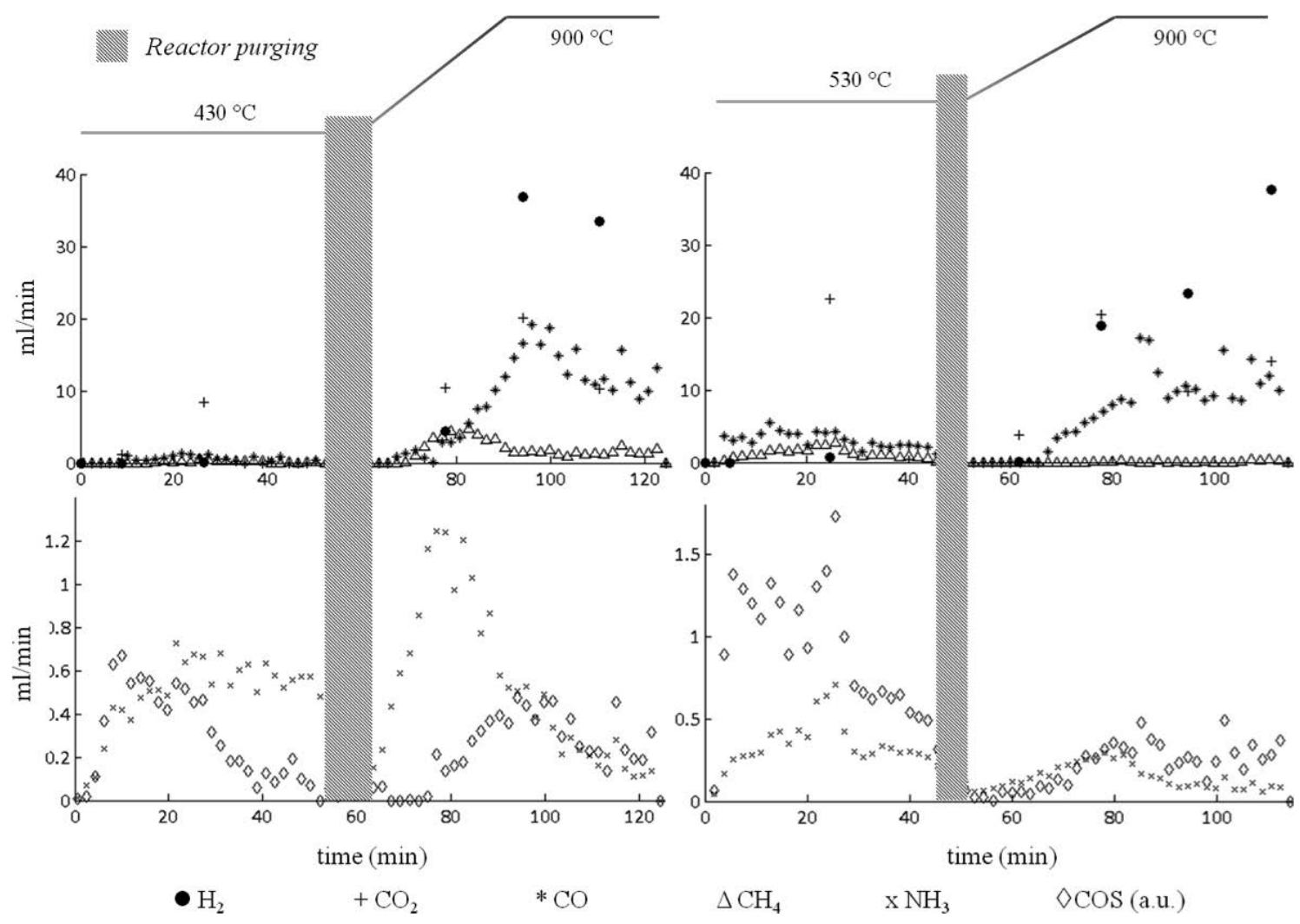

Figure 9. $\mathrm{H}_{2}, \mathrm{CO}_{2}, \mathrm{CO}, \mathrm{CH}_{4}, \mathrm{NH}_{3}$, and $\mathrm{COS}$ production, in $\mathrm{mL} \mathrm{min}{ }^{-1}$ under standard conditions, during the staged SSG experiments with a cleanup stage at $430^{\circ} \mathrm{C}$ (right) and $530^{\circ} \mathrm{C}$ (left).

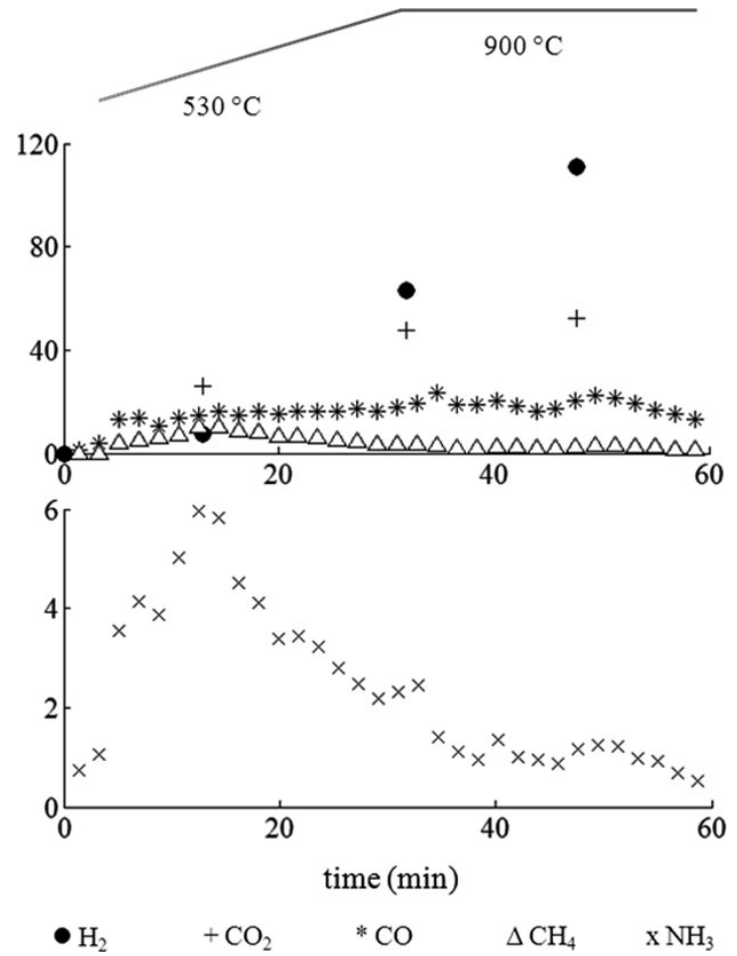

Figure 10. $\mathrm{H}_{2}, \mathrm{CO}_{2}, \mathrm{CO}, \mathrm{CH}_{4}$, and $\mathrm{NH}_{3}$, in $\mathrm{mL} \mathrm{min}^{-1}$ under standard conditions, during the simple SSG experiment. was between $22-57.5$ a.u. while during the second stage it was always below 10 a.u. More information about the COS behavior, and the possible decomposition or reaction, would be necessary to quantify the $S$ reduction in the SSG producer gas. However, these experiments prove the partial removal of $S$ during the cleanup stage.

Despite the effectiveness of the cleanup stage in pollutant removal, a considerable reduction in the production of combustible compounds was also observed. The CO production during the gasification stages, the second stages of the staged experiments, represented between 81 and $118.8 \mathrm{~mL}_{\mathrm{CO}} \mathrm{g}_{\mathrm{DSS}}^{-1}$, while the $\mathrm{CO}$ in the producer gas of the simple gasification represented about $156 \mathrm{~mL}_{\mathrm{CO}} \mathrm{g}_{\mathrm{DSS}}^{-1}$. This means that the efficiency in $\mathrm{C}$ conversion to $\mathrm{CO}$ for the staged gasification is between 15 and $20 \%$, instead of $26 \%$ for the simple gasification. $\mathrm{H}_{2}$ production was also affected by the cleanup stage. It was of about $492 \mathrm{~mL}_{\mathrm{H}_{2}} \mathrm{~g}_{\mathrm{DSS}}^{-1}$ for the simple gasification and below $293 \mathrm{~mL}_{\mathrm{H}_{2}} \mathrm{~g}_{\mathrm{DSS}}^{-1}$ for the second stages of the staged gasification. At this point, it should be kept in mind that the aim of the staged SSG is to limit the pollutant contents in the producer gas, avoiding post-treatment energy consumption. Nevertheless, it is believed that the loss in producer gas energetic value could be avoided or almost avoided by better controlling the cleanup stage operative conditions, e.g., temperature, gasifying agent, residence time, etc. Therefore, this work provides guidelines to carry out a larger study of the proposed process in a continuously fed installation in order to determine the optimal 
Table 4. Total $\mathrm{H}_{2}, \mathrm{CO}, \mathrm{NH}_{3}$ and COS produced during the staged and simple SSG experiments.

\begin{tabular}{|c|c|c|c|c|c|}
\hline & & \multicolumn{2}{|c|}{ Combustibles } & \multicolumn{2}{|c|}{ Pollutant precursors } \\
\hline & & $\mathrm{CO}\left[\mathrm{mg} \mathrm{g}_{\mathrm{C}-\mathrm{SS}}^{-1}\right]$ & $\mathrm{H}_{2}\left[\mathrm{mgg} \mathrm{g}_{\mathrm{C}-\mathrm{SS}}^{-1}\right]$ & $\mathrm{NH}_{3}\left[\mathrm{mg} \mathrm{g}_{\mathrm{N}-\mathrm{SS}}^{-1}\right]$ & COS [a.u.] \\
\hline \multirow[t]{8}{*}{ Staged gasification } & Cleanup stage & & & & \\
\hline & at $430^{\circ} \mathrm{C}$ & 45.4 & n.d. & 124.6 & 45.6 \\
\hline & at $480^{\circ} \mathrm{C}$ & 42.6 & n.d. & 95.2 & 22.6 \\
\hline & at $530^{\circ} \mathrm{C}$ & 66.0 & n.d. & 151.7 & 57.5 \\
\hline & Gasification stage at $900^{\circ} \mathrm{C}$ & & & & \\
\hline & char 430 & 157.9 & 59.1 & 35.8 & 9.9 \\
\hline & char 480 & 199.0 & n.d. & 23.7 & 8.4 \\
\hline & char 530 & 152.8 & 67.7 & 28.5 & 6.5 \\
\hline $\begin{array}{l}\text { Simple gasification } \\
\text { at } 900^{\circ} \mathrm{C}\end{array}$ & & 264.5 & 135.0 & 271.5 & n.d. \\
\hline
\end{tabular}

n.d.: Not detected; C-SS: carbon contained in the SS sample; N-SS: nitrogen contained in the SS sample.

temperature for maximizing the removal of $\mathrm{N}$ and $\mathrm{S}$ compounds and for limiting the detrimental effects on the producer gas. However, in view of the results discussed here, staged SSG is a suitable alternative to restrict the presence of pollutant precursors in the producer gas, avoiding the formation of pollutants during the final combustion.

\section{Conclusions}

This study proposes a staged gasification process dealing with waste fuel conversion into a producer gas with limited content of pollutants. Two stages were considered: (i) a low-temperature cleanup stage aiming to remove the pollutant precursors from the fuel and (ii) a gasification stage aiming to produce combustible compounds. This approach was applied to SS in order to handle $\mathrm{N}$ and $\mathrm{S}$ pollutant precursors.

Firstly, the gas produced by SS devolatilization with steam atmosphere, at temperatures below $530^{\circ} \mathrm{C}$, in a batch laboratory-scale reactor was analyzed by FTIR and GC, completing really scarce data. Comparison between elemental analyses before and after the experiments showed the global composition of the devolatilization gas, in each temperature range. Pollutant precursors were identified and surveyed, by FTIR coupled with an original chemometric tool (SIMPLISMA) and RTD calculations. Also, the Arrhenius law was applied to determine kinetic parameters of $\mathrm{CO}$ and $\mathrm{NH}_{3}$ production. From this initial study, a number of conclusions can be drawn:

- The main gas compounds released during SS devolatilization with steam $\left(<530^{\circ} \mathrm{C}\right)$ are $\mathrm{CO}_{2}, \mathrm{H}_{2} \mathrm{O}, \mathrm{CO}, \mathrm{NH}_{3}, \mathrm{HCN}$, $\mathrm{HCNO}, \mathrm{CH}_{4}, \mathrm{CH}_{3}-\mathrm{COOH}, \mathrm{CH}_{3}-\mathrm{OH}, \mathrm{C}_{2} \mathrm{H}_{6}$, and COS.

- Among these compounds, $\mathrm{NH}_{3}$ and COS are the main $\mathrm{N}$ and $\mathrm{S}$ pollutant precursors. Their presence in the gasification producer gas should be avoided in order to prevent $\mathrm{NO}_{\mathrm{x}}$ and $\mathrm{SO}_{\mathrm{x}}$ formation during the final combustion.

- $\mathrm{NH}_{3}$ and COS removal during the cleanup stage is favored at higher temperature, especially at temperatures around $530^{\circ} \mathrm{C}$. Between 430 and $530^{\circ} \mathrm{C}$, the devolatilization mecha- nisms change (higher-temperature mechanism), and $\mathrm{NH}_{3}$ and COS production increases sharply between those temperatures.

- The lumped activation energies of $\mathrm{CO}$ and $\mathrm{NH}_{3}$ production during the cleanup stage $\left(230-530^{\circ} \mathrm{C}\right)$ are 41 and $44 \mathrm{~kJ} \mathrm{~mol}^{-1}$, respectively.

Secondly, the producer gases of staged gasification (after a cleanup stage at 430,480 , and $530{ }^{\circ} \mathrm{C}$ ) were compared with the producer gas of simple gasification. The cleanup stage implies a reduction on the combustible value of the producer gas, which may be overcome by further optimization of this innovative process. Finally, the cleanup stage, carried out between $430-530^{\circ} \mathrm{C}$, considerably prevents the formation of pollutants; ammonia removal was between $87-98 \%$.

\section{Acknowledgment}

The authors would like to thank the Research Federation ECCOREV for partially financing this work, as well as JeanClaude Boutemy for the supply of ceramic support. Ana Belén Hernández would like to acknowledge a scholarship from the French Minister of Higher Education and Research.

The authors have declared no conflict of interest.

\section{References}

[1] Milieu Ltd., WRc, Report for the European Commission, ENV.G.4/ETU/2008/0076r, Brussels 2009.

[2] D. Fytili, A. Zabaniotou, Renewable Sustainable Energ. Rev. 2008, 12 (1), 116.

[3] Urban Waste Water Treatment Directive (UWWTD, 91/271/ EEC), European Commission, Brussels 1991.

[4] Council Directive of 12 June 1986 on the protection of the environment, and in particular of the soil, when sewage 
sludge is used in agriculture (86/278/EEC), European Commission, Brussels 1986.

[5] Council Directive of 26 April 1999 on the landfill of waste (1999/31/EC), European Commission, Brussels 1999.

[6] J. Werther, T. Ogada, Prog. Energy Combust. Sci. 1999, 25 (1), 55.

[7] Council Directive on the incineration of waste (the WI Directive, 2000/76/EC), European Commission, Brussels 2000.

[8] S. Donatello, M. Tyrer, C. R. Cheeseman, Waste Manage. 2010, 30 (1), 63.

[9] M. Hartman, M. Pohorely, O. Trnka, Chem. Papers 2007, 61 (3), 181.

[10] N. Lapa, R. Barbosa, M. H. Lopes, B. Mendes, P. Abelha, I. Gulyurtlu, J. Santos Oliveira, J. Hazard. Mater. 2007, 147 (1/2), 175.

[11] K. Karlfeldt Fedje, C. Ekberg, G. Skarnemark, B.-M. Steenari, J. Hazard. Mater. 2010, 173 (1-3), 310.

[12] L. Wang, G. Skjevrak, J. E. Hustad, M. G. Gronli, Fuel Process. Technol. 2012, 96, 88.

[13] J.-H. Ferrasse, I. Seyssiecq, N. Roche, Chem. Eng. Technol. 2003, 26 (9), 941.

[14] A. B. Hernandez, J.-H. Ferrasse, P. Chaurand, H. Saveyn, D. Borschneck, N. Roche, J. Hazard. Mater. 2011, 191 (1-3), 219.

[15] H. Liu, H. Zhu, M. Kaneko, S. Kato, T. Kojima, Energy Fuels 2009, 24 (1), 68.

[16] S. Wu, J. Gu, L. Li, Y. Wu, J. Gao, Process Saf. Environ. Prot. 2006, 84 (6), 420.

[17] A. Gomez-Barea, S. Nilsson, F. Vidal Barrero, M. Campoy, Fuel Process. Technol. 2010, 91 (11), 1624.

[18] S. Nilsson, A. Gomez-Barea, D. F. Cano, Fuel 2012, 92 (1), 346.

[19] J. A. Conesa, A. Marcilla, D. Prats, M. Rodriguez-Pastor, Waste Manage. Res. 1997, 15 (3), 293.

[20] J. A. Conesa, A. Marcilla, R. Moral, J. Moreno-Caselles, A. Perez-Espinosa, Thermochim. Acta 1998, 313 (1), 63.

[21] R. Font, A. Fullana, J. A. Conesa, F. Llavador, J. Anal. Appl. Pyrolysis 2001, 58/59, 927.

[22] S. A. Scott, J. F. Davidson, J. S. Dennis, A. N. Hayhurst, Chem. Eng. Sci. 2007, 62 (1/2), 584.

[23] G. Skodras, P. Grammelis, M. Prokopidou, E. Kakaras, G. Sakellaropoulos, Fuel 2009, 88 (7), 1201.

[24] A. Midilli, M. Dogru, G. Akay, C. R. Howarth, Int. J. Hydrogen Energy 2002, 27 (10), 1035.

[25] J. J. Manyà, J. L. Sánchez, J. Ábrego, A. Gonzalo, J. Arauzo, Fuel 2006, 85 (14/15), 2027.

[26] J. J. Manyà, J. Sanchez, A. Gonzalo, J. Arauzo, Energy Fuels 2005, 19 (2), 629.

[27] A. Midilli, M. Dogru, C. R. Howarth, M. J. Ling, T. Ayhan, Energy Convers. Manag. 2001, 42 (2), 157.

[28] I. Petersen, J. Werther, Chem. Eng. Process. 2005, 44 (7), 717.

[29] J. M. de Andrés, A. Narros, M. E. Rodríguez, Fuel Process. Technol. 2011, 92 (3), 433.

[30] M. Dogru, A. Midilli, C. R. Howarth, Fuel Process. Technol. 2002, 75 (1), 55.

[31] H. Saveyn, J.-H. Ferrasse, A. B. Hernandez, J. Rose, P. Van der Meeren, N. Roche, J. Residuals Sci. Technol. 2011, 8 (2), 61.
[32] T. W. Marrero, B. P. McAuley, W. R. Sutterlin, J. Steven Morris, S. E. Manahan, Waste Manage. 2004, 24 (2), 193.

[33] G. P. Reed, N. P. Paterson, Y. Zhuo, D. R. Dugwell, R. Kandiyoti, Energy Fuels 2005, 19, 298.

[34] A. Adegoroye, N. Paterson, X. Li, T. Morgan, A. A. Herod, D. R. Dugwell, R. Kandiyoti, Fuel 2004, 83 (14/15), 1949.

[35] M. Aznar, J. J. Manyà, G. Garcia, J. L. Sanchez, M. B. Murillo, Energy Fuels 2008, 22 (4), 2840.

[36] T. Phuphuakrat, N. Nipattummakul, T. Namioka, S. Kerdsuwan, K. Yoshikawa, Fuel 2010, 89 (9), 2278.

[37] T.-Y. Mun, P.-G. Seon, J.-S. Kim, Fuel 2010, 89 (11), 3226.

[38] J. Han, H. Kim, Renewable Sustainable Energ. Rev. 2008, 12 (2), 397.

[39] L. Devi, K. J. Ptasinski, F. J. J. G. Janssen, Biomass Bioenergy 2003, 24 (2), 125.

[40] P. Vriesman, E. Heginuz, K. Sjöström, Fuel 2000, 79 (11), 1371.

[41] H. Liu, B. M. Gibbs, Fuel 2002, 81 (3), 271.

[42] H. Liu, B. M. Gibbs, Fuel 2003, 82 (13), 1591.

[43] G. Stubenberger, R. Scharler, S. Zahirovic, I. Obernberger, Fuel 2008, 87 (6), 793.

[44] J. Leppälahti, T. Koljonen, Fuel Process. Technol. 1995, 43 (1), 1.

[45] H. Hu, Q. Zhou, S. Zhu, B. Meyer, S. Krzack, G. Chen, Fuel Process. Technol. 2004, 85 (8-10), 849.

[46] D. Shao, E. J. Hutchinson, J. Heidbrink, W.-P. Pan, C.-L. Chou, J. Anal. Appl. Pyrolysis 1994, 30 (1), 91.

[47] M. R. Khan, Fuel 1989, 68 (11), 1439.

[48] J. V. Ibarra, A. J. Bonet, R. Moliner, Fuel 1994, 73 (6), 933.

[49] F. Garcia-Labiano, E. Hampartsoumian, A. Williams, Fuel 1995, 74 (7), 1072.

[50] M. Aznar, M. S. Anselmo, J. J. Manyà, M. B. Murillo, Energy Fuels 2009, 23 (6), 3236.

[51] N. Paterson, Y. Zhuo, D. Dugwell, R. Kandiyoti, Energy Fuels 2005, 19 (3), 1016.

[52] J.-P. Cao, L.-Y. Li, K. Morishita, X.-B. Xiao, X.-Y. Zhao, X.-Y. Wei, T. Takarada, Fuel 2013, 104, 1-6.

[53] A. Fullana, J. A. Conesa, R. Font, I. Martín-Gullón, J. Anal. Appl. Pyrolysis 2003, 68/69, 561.

[54] F.-J. Tian, B.-Q. Li, Y. Chen, C.-Z. Li, Fuel 2002, 81 (17), 2203.

[55] T. Bui, R. Loof, S. C. Bhattacharya, Energy 1994, 19 (4), 397.

[56] U. Henriksen, J. Ahrenfeldt, T. K. Jensen, B. Gøbel, J. D. Bentzen, C. Hindsgaul, L. H. Sørensen, Energy 2006, 31 (10/11), 1542.

[57] T.-Y. Mun, B.-S. Kang, J.-S. Kim, Energy Fuels 2009, 23 (6), 3268.

[58] Y. Zhang, Y. Wang, L. Cai, C. Yao, S. Gao, C.-Z. Li, G. Xu, Fuel 2012, 112, 624. DOI: 10.1016/j.fuel.2012.01.038

[59] S. Nilsson, A. Gomez-Barea, D. Fuentes-Cano, P. Ollero, Fuel 2012, 97, 730 .

[60] P. Girods, A. Dufour, Y. Rogaume, C. Rogaume, A. Zoulalian, J. Anal. Appl. Pyrolysis 2009, 85 (1/2), 171.

[61] W.-Y. Deng, J.-H. Yan, X.-D. Li, F. Wang, X.-W. Zhu, S.-Y. Lu, K.-F. Chen, J. Hazard. Mater. 2009, 162 (1), 186.

[62] Biological Wastewater Treatment. Principles, Modelling and Design (Eds: M. Henze, M. C. M. van Loosdrecht, G. A. Ekama, D. Brdjanovic), IWA Publishing, London 2008.

[63] W. Windig, Chemom. Intell. Lab. Syst. 1997, 36 (1), 3. 
[64] J.-H. Ferrasse, S. Chavez, P. Arlabosse, N. Dupuy, Thermochim. Acta 2003, 404, 97.

[65] A. B. Hernandez, Ph.D. Thesis, Aix-Marseille Université 2012.

[66] N. Piatkowski, A. Steinfeld, Fuel 2009, 89 (5), 1133.

[67] C. Casajus, J. Abrego, F. Marias, J. Vaxelaire, J. L. Sánchez, A. Gonzalo, Chem. Eng. J. (Lausanne) 2009, 145 (3), 412.

[68] L. A. Haas, S. E. Khalafalla, J. Catal. 1973, 30 (3), 451.
[69] L. A. Haas, S. E. Khalafalla, J. Catal. 1973, 29 (2), 264.

[70] J. Yu, L. Chang, W. Xie, D. Wang, Korean J. Chem. Eng. 2011, 28 (4), 1054.

[71] A. Ji, S. Zhang, X. Lu, Y. Liu, Waste Manage. 2010, 30 (7), 1225.

[72] G. Pantoleontos, P. Basinas, G. Skodras, P. Grammelis, J. D. Pinter, S. Topis, G. P. Sakellaropoulos, Fuel Process. Technol. 2009, 90 (6), 762. 